\title{
Vulnerability of Rice Farmers to Climate Change in Kwara State, Nigeria
}

\author{
Sheu-Usman Oladipo Akanbi ${ }^{1, a, *}$, Olanrewaju Solomon Olatunji ${ }^{1, b}$, Olamide Sulaiman Oladipo ${ }^{1, c}$, \\ Uswat Temitayo Adeyemi ${ }^{1, \mathrm{~d}}$, Akinyinka Akinyoade ${ }^{2, \mathrm{e}}$ \\ ${ }^{1}$ Department of Agricultural Economics and Farms Management, Faculty of Agriculture, P.M.B 1515, University of Ilorin, Nigeria \\ ${ }^{2}$ Africa Studies Centre,Faculty of Social Sciences, Leiden University, Netherlands
} *Corresponding author

\begin{tabular}{|c|c|}
\hline A R T I C L E I N F O & A B S T R A C T \\
\hline $\begin{array}{l}\text { Keywords: } \\
\text { Vulnerability } \\
\text { Rice farmers } \\
\text { Climate change } \\
\text { Coping Strategies } \\
\text { Food Production }\end{array}$ & $\begin{array}{l}\text { Climate unpredictability and weather extremes are being projected as capable of presenting } \\
\text { additional challenges for farmers currently engaged in the low-technology based food production } \\
\text { systems in sub-Saharan countries like Nigeria. This study assessed rice farming households' } \\
\text { vulnerability to climate change in Kwara State, Nigeria. Primary data, collected from } 150 \\
\text { respondents using simple random sampling procedure were analysed employing descriptive statistic } \\
\text { was use to describe the coping strategies adopted and Human Development Index (HDI) was created } \\
\text { to assess vulnerability of rice farmers to climate change. Statistical analyses indicated a } \\
\text { vulnerability assessment index of } 0.3001 \text {, pointing to a fact that the zone is prone to the adverse } \\
\text { effects of climatic variability. For this reason, the study empirically underscores the need for farmers } \\
\text { to adopt and adapt the planting of drought tolerant and/or early maturing varieties of rice. } \\
\text { Importantly, the capacities of the local communities needs to be strengthened vis-à-vis the } \\
\text { relationship between climate change and crop production. Capacity building at the farm level is } \\
\text { crucial for improving crop, soil and water management, enhancing the demand for and use of better } \\
\text { and more efficient production inputs. Tied to farm-level capacity building is the need to refocus } \\
\text { public agricultural-based institutions towards exposing the rice farmers to effective mitigation } \\
\text { strategies in the wake of climate change, provision of agricultural inputs, expansion of irrigation, } \\
\text { efficient and effective extension service delivery, market development and other forms of necessary } \\
\text { support. }\end{array}$ \\
\hline
\end{tabular}

\section{Introduction}

The Nigerian Meteorological Agency recorded remarkable changes in the country's weather pattern from 1941 to 2018 rainfall in the northern parts had been on a steady decline since the early 1970s while that of the southern areas fluctuated year in, year out. Correspondingly, the temperatures in the north had also increased over the same period, with an average increase of between $1.4-1.9^{\circ} \mathrm{C}$; scientists have warned that it could further increase to between $2.0-5.0^{\circ} \mathrm{C}$ before the century ends, if no drastic action is taken (Nwajiuba, 2013). These sets of data on changes in weather patterns are signposts ongoing changes in Nigeria's climate. Farmers in the country are in a major part subsistent in practice, many of which also into rain-fed agricultural practice.
Two theories that resonate with the concept of climate change and vulnerability of farmers to its effect were considered for this particular study. The first is the theory of Climate signal. The climate signal has to do with the long-term changes in average climate conditions, as well as the changes in climate inconsistency vis-à-vis changes in the timing, intensity and duration of precipitation and extreme weather events, like droughts and floods (Smithers and Smit 1997). They stated that the coping strategy adopted by most persons at the receiving end largely depends on the characteristics of the climate stimulus visà-vis the level of exposure to the stress and the scale and magnitude of the event. 
The second is the theory of 'context of vulnerability' which posits that the effect of climate change on the wellbeing of individuals, households, and communities and their ability to respond to those changes depends on the context in which climate change occurs (Adger et al., 2009). The context includes all the factors that determine an individual's, households, groups, or community's vulnerability to climate change.

Agriculture in sub-Saharan Africa is largely weather dependent and any change in climate may lead to downshift in productivity; thus, poor and unpredictable yields is occasioned and thereby making farmers more vulnerable (UNFCCC, 2007). One crop that is has been caught up in the devastating effect of climate induced environmental tragedy is rice. The rice crop is a staple food of virtually every household in Nigeria, both the rich and poor consume large quantity of rice every day. (Uba, 2013) noted that $70 \%$ of a total projected population of Nigeria feed on rice.

Nigeria is said to be Africa largest producer of rice among the top 15 globally. Processed rice grain consumption was up by more than three-fold from $9.2 \mathrm{Mt}$ to $31.5 \mathrm{Mt}$ during the period of 1990 to date in SSA (United States Department of Agriculture, 2018). Research revealed that between 2003 and 2013, Nigeria imported $17,206,077$ tons of rice with an average import at 1,564,188 million (United States Department of Agriculture, 2018). Table 1 below shows rice production trends in Nigeria from $(2010-2018)$.

Table 1. Rice Production Trends in Nigeria from 2010-2018

\begin{tabular}{c|ccc}
\hline Year & Production & $\begin{array}{c}\text { Unit of } \\
\text { Measure }\end{array}$ & $\begin{array}{c}\text { Growth Rate } \\
(\%)\end{array}$ \\
\hline 2010 & 2818 & $(1000 \mathrm{MT})$ & 26.14 \\
2011 & 2906 & $(1000 \mathrm{MT})$ & 3.12 \\
2012 & 3423 & $(1000 \mathrm{MT})$ & 17.79 \\
2013 & 3038 & $(1000 \mathrm{MT})$ & -11.25 \\
2014 & 3782 & $(1000 \mathrm{MT})$ & 24.49 \\
2015 & 3941 & $(1000 \mathrm{MT})$ & 4.20 \\
2016 & 3780 & $(1000 \mathrm{MT})$ & -4.09 \\
2017 & 3780 & $(1000 \mathrm{MT})$ & 0.00 \\
2018 & 3780 & $(1000 \mathrm{MT})$ & 0.00 \\
\hline
\end{tabular}

Source: United States Department of Agriculture (2018)

The adverse effect of variations in the seasonal weather conditions is already manifesting across a wide range of natural and human activities. The changing rainfall patterns and rising temperatures of the earth were particularly ranked as major contributors to the now rampant disasters like droughts, floods and forest fires (Zoellick, 2009). These environmentally-induced challenges have made many farmers, whose livelihood depends majorly on agricultural production, become more and more susceptible to climate risk.

Recently, Nigeria witnessed some devastating floods that were reported to have been worst of its kind in Nigeria; thousands of farmers were not only displaced from their homes but large quantities of food crops were also swept away, thereby threatening food security status of the nation (Punch newspaper, 2018).

One of the crops worst hit by the flooding is rice which is a major staple crop in the country. Rice is an important crop in Patigi, Lafiagi, Tsonga and their surrounding areas in Kwara State, Nigeria. These areas which lie within the flooding vulnerable zone had certainly aroused the interest to carrying out this study.

The open questions therefore are, "to what extent are rice farmers in the study area aware of climate change?" "How vulnerable are the rice farmers to climate risk?" and "How do the farmers respond to climate induced shocks?"

Although farmers manage at multiple scales, their adaptation decisions are primarily driven by private benefits reaped in the here and now (Jackson et al., 2010). Instances of adaptation of agriculture to the impacts of climate change might include adjustments in planting dates, crop varieties, drainage systems, and land management regimes to maintain yields and soil fertility. Over time, shifts in annual averages and seasonal patterns of precipitation, temperature, and humidity, as well as more erratic and extreme weather events leading to increased risk of floods, drought, and fire are anticipated for the future (Coumou and Rahmstorf, 2012; Hatfield et al., 2011).

It is pertinent for farmers to be aware of climate change, behavior change is influenced by perceptions of the risks associated with a given natural hazard, which are mediated by beliefs about the existence of the hazard and its characteristics. Perceived risk among individuals or group of people, while a critical determinant of willingness to prepare for or mitigate natural hazards, is often at odds with objective assessments of risk (Nigg and Mileti, 2002). In other words, perceptions of risk are socially constructed and transmitted, differences in worldviews, personal experiences, expectations about technology, trust in institutions, and other factors can influence awareness and understanding of hazards and decisions and actions (or inaction) in response (Slovic, 2009). Studies on vulnerability of rice farmers to the effects of climate change are still in the budding stage in Nigeria, this exploratory study, therefore, will be of benefit to the farming households in general and rice farmers in particular, in helping them to take necessary mitigation measures. Students as well as researchers will also benefit from the study as it will contribute in filling the existing gap in the study of risk management among farming households in the locality.

\section{Material and Methods}

\section{Study Area}

The study was carried out in Kwara State, Nigeria which is located between latitudes $8^{\circ} 30^{\prime}$ and $8^{\circ} 50^{\prime} \mathrm{N}$ and longitudes $4^{\circ} 20^{\prime}$ and $4^{\circ} 35^{\prime} \mathrm{E}$ of the equator. The wet season straddles the months of March to November and the annual rainfall varies from $1000 \mathrm{~mm}$ to $1500 \mathrm{~mm}$, attaining its peak around September to early October (KWADP, 2018).

Also, the mean monthly temperature is moderately high throughout the year. The daily average temperature is $25^{\circ} \mathrm{C}$ in the month of January, $27.5^{\circ} \mathrm{C}$ in May and $22.5^{\circ} \mathrm{C}$ in September (KWADP, 2018).

The common vegetation type found in the state is derived Savannah with riparian forest along banks of rivers. The major occupation of the people in the state is farming and various crops are cultivated at subsistence level which they consume by farmers' families. Rice is one of the common crops cultivated and it is largely weather 
dependent. Other crops cultivated by farmers in the State include sorghum, cassava, maize, yam, beans and sweet potatoes are the major crops; a few farmers also grow cash crops like cashew and oil palm (KWADP, 2018).

\section{Sampling Techniques and Methodology}

The sampling frame was developed from the list of rice farmers in the Ministry of Agriculture and Rural Development, Kwara State, Nigeria. A random selection of 150 rice farmers was undertaken and questionnaire was administered on them to obtain relevant data. The analytical tools employed for this study include descriptive statistics, Vulnerability Assessment and a 5-point Likerttype scale that was employed in ranking the coping strategies adopted by the rice farmers.

\section{Vulnerability Assessment}

Normalization of indicators using functional relationship was adapted from the Human Development Index (HDI) used by United Nation Development Programme, (UNDP, 2006) and Organization for Economic Co-operation and Development, (OECD, 2008) - this involves ensuring that all the indicator values are comparable and congruent such that they are standardized to fit within the range zero (0) to one (1) - adopting linear normalization:

$$
\mathrm{Zij}=\frac{\operatorname{Max}\left\{\mathrm{X}_{\mathrm{ij}}\right\}-\mathrm{X}_{\mathrm{ij}}}{\operatorname{Max}\left\{\mathrm{X}_{\mathrm{ij}}\right\}-\operatorname{Min}\left\{\mathrm{X}_{\mathrm{ij}}\right\}}
$$

$$
\begin{aligned}
& \text { Where } \\
& Z_{i j}=\text { normalized value of indicator } \mathrm{i} \\
& \mathrm{X}_{\mathrm{ij}}=\text { value of indicator } \mathrm{i} \\
& \operatorname{Max}\left\{\mathrm{X}_{\mathrm{ij}}\right\}=\text { highest value } \\
& \operatorname{Min}\left\{\mathrm{X}_{\mathrm{ij}}\right\}=\text { lowest value }
\end{aligned}
$$

Aggregation of indicators: This is a linear summation aggregation method. Index (I) of the indicator $\mathrm{Y}$ for a farming community/village (i) was calculated by multiplying its weight (Wy), by its normalized value $\left(\mathrm{N}_{\mathrm{yi}}\right)$ which is the standardized value of the indicator.

$$
\mathrm{I}_{\mathrm{yi}}=\mathrm{W}_{\mathrm{y}} \times \mathrm{N}_{\mathrm{yi}}
$$

$$
\begin{aligned}
& \text { Where } \\
& \mathrm{I}_{\mathrm{yi}}=\text { Vulnerability index of } \mathrm{i} \text { household } \\
& \mathrm{W}_{\mathrm{y}}=\text { Weight of the indicator } \\
& \mathrm{N}_{\mathrm{yi}}=\text { Standardized value of the indicator }
\end{aligned}
$$

The Vulnerability Index (Iv) of each component of vulnerability (Exposure, Susceptibility and Capacity) was computed as the arithmetic mean of the values of all indices of the component for farmers. Given a component of vulnerability with indicators $\mathrm{Y}$, measured for a farmer/farming community/village (i), then the Vulnerability Index (Iv) of the component of vulnerability in that particular farmer/farming community/village (i) is given by:

$$
\mathrm{I}_{\mathrm{v}}=\frac{\sum\left(\mathrm{w}_{\mathrm{y}} \times \mathrm{N}_{\mathrm{yi}}\right)}{\mathrm{n}}
$$

Where $\mathrm{n}=$ number of indicators of the component of vulnerability. Vulnerability increases with exposure and susceptibility but reduces with capacities. The vulnerability index so computed lies between 0 and 1 , with 1 indicating maximum vulnerability and 0 indicating no vulnerability at all.

\section{Rice Farmer's Coping Strategy Index}

$$
\text { RFSUI }=\frac{\left(\mathrm{N}_{1} \times 3\right)+\left(\mathrm{N}_{2} \times 2\right)+\left(\mathrm{N}_{3} \times 1\right)}{\mathrm{M}}
$$

Where

RFSUI $=$ Rice farmers adaptation strategy use index

$\mathrm{N}_{1}=$ Number of farm that constantly use a particular CS;

$\mathrm{N}_{2}=$ Number of farm that occasionally use a particular CS;

$\mathrm{N}_{3}=$ Number of farm that rarely use a particular CS;

$\mathrm{M}=\mathrm{n} \times 3$;

$\mathrm{n}=$ Total number of respondents

\section{Results and Discussion}

Socio-economic Characteristics of the Rice Farmers

Table 2 indicates that majority of the respondents are between the ages of 30 years and above; respondents found in age 26 years and over accounted for two-thirds (68.0\%) of the rice farmers. This signifies ageing among rice farmer, finding shows that $59.3 \%$ of the respondents were males while $40.6 \%$ were females. Although more males involved in rice farming but with these findings it also confirmed a widely held notion that reasonable numbers of female farmers were fully involved in rice farming.

A majority (58.7\%) of the respondents interviewed in the study area were married and the modal family size is between 4-6 people - the family size is a good indicator of potential family labour that is rampant especially among smallholder farmers.

Table 2 also shows that majority $70.0 \%$ of the respondents have primary education which is the highest among other categories of education in the study area. It was confirmed by the majority $62.7 \%$ of the respondents that they do not belong to any association while only $37.3 \%$ claimed to belong to one association or the other. Large number of the respondents $64.7 \%$ claimed to have access to extension service while only $35.3 \%$ confirmed not having access to extension service. For those that have access to extension service the record shows that the highest number of visits was between 1-5 within one farming season.

Table 2 shows that over average $57.3 \%$ of the respondents claimed that farming is not their primary occupation. [indicate other things that they do in addition]. About a half of the respondents $(50 \%)$ have between 1-5 hectares of land for their rice farming. The highest frequency for years of farming is ranges between 5-10 years with about $27.3 \%$ of the respondents stated to have up to this number of years of farming experience.

\section{Level of Awareness about climate elements by Rice Farmers}

Table 3 categorizes the responses of the rice farmers to some pertinent questions that have to do with the adverse effect of climate on rice production. Majority (87.1\%) affirmed awareness of the effect of climate change while only 12.9 claimed not to be aware of the changing climate pattern. 
Table 2. Socio-economic Characteristics of the Rice Farmers

\begin{tabular}{|c|c|c|}
\hline Variables & $\mathrm{F}$ & $\mathrm{P}$ \\
\hline \multicolumn{3}{|c|}{ Age } \\
\hline $16-20$ & 15 & 10.0 \\
\hline $21-25$ & 33 & 22.0 \\
\hline $26-30$ & 46 & 30.7 \\
\hline+30 years & 56 & 37.3 \\
\hline \multicolumn{3}{|c|}{ Gender } \\
\hline Male & 89 & 59.3 \\
\hline Female & 61 & 40.6 \\
\hline \multicolumn{3}{|c|}{ Marital Status } \\
\hline Single & 44 & 29.3 \\
\hline Married & 88 & 58.7 \\
\hline Divorce & 18 & 12.0 \\
\hline \multicolumn{3}{|c|}{ Family Size } \\
\hline $1-3$ & 12 & 8.0 \\
\hline $4-6$ & 88 & 58.7 \\
\hline $7-10$ & 29 & 19.3 \\
\hline $10+$ & 21 & 14.0 \\
\hline \multicolumn{3}{|c|}{ Education Status } \\
\hline No Formal Education & 28 & 18.7 \\
\hline Primary Education & 105 & 70.0 \\
\hline Secondary \& Higher School & 17 & 11.3 \\
\hline \multicolumn{3}{|c|}{ Membership of Association } \\
\hline No & 94 & 62.7 \\
\hline Yes & 56 & 37.3 \\
\hline \multicolumn{3}{|c|}{ Extension Service } \\
\hline No & 53 & 35.3 \\
\hline Yes & 97 & 64.7 \\
\hline \multicolumn{3}{|c|}{ No of Contact } \\
\hline 0 & 53 & 35.3 \\
\hline $1-5$ & 79 & 52.7 \\
\hline $6-10$ & 11 & 7.3 \\
\hline$>10$ & 7 & 4.7 \\
\hline \multicolumn{3}{|c|}{ Primary Occupation } \\
\hline Farming & 64 & 42.7 \\
\hline Non- Farming & 86 & 57.3 \\
\hline \multicolumn{3}{|c|}{ Years of Farming } \\
\hline$<5$ & 4 & 2.7 \\
\hline $5-10$ & 41 & 27.3 \\
\hline $11-15$ & 38 & 25.3 \\
\hline $16-20$ & 35 & 23.3 \\
\hline$>20$ & 32 & 21.4 \\
\hline \multicolumn{3}{|c|}{ Farm Size (Ha) } \\
\hline$<1$ & 52 & 34.7 \\
\hline $1-5$ & 70 & 46.7 \\
\hline $6-10$ & 11 & 7.3 \\
\hline$>10$ & 17 & 11.3 \\
\hline
\end{tabular}

F: Frequency, P: Percentage (\%), Source: Field Survey

Most of the respondents (75.9\%) confirmed to have been affected by climate change in the course of production of rice while $24.1 \%$ claimed not to be affected by the climate change. Their perceptions of climate change were explored in a series of questions, responses to which are provided hereafter.

In an area where agriculture is mostly rain-fed, and water very important especially not for the dry paddy variety, the predictability of rain water is important for the rice farmers agronomic. One of the pertinent questions asked therefore was whether the rainfall is predictable and fewer respondents $(40.7 \%$ ) claimed that rainfall has predictable. Predictability of water availability is important for practices on-set of planting, gestation, and harvesting.
It impinges on quality of rice produce depending on how much or how less water is available. This has a roll-on effect on harvests and income potentials, which invariably indicate eventual incomes for farmers whose farming practices are not diversified or mixed with other farming activities

Another important aspect of the question is that has to do whether they have ever experience flooding in their community and a larger percentage $66.7 \%$ claim to experience flood. The respondents' perception was compared with figures of temperature and rainfall that were obtained from the meteorological station.

Level of Perception of Farmers on Climate Change Effect

The most perceived climate change element among others is reduction in crop productivity which has to do with the quantity produced not measuring up to the size of the land in use. Their perception of this particular element was based on the resultant yield which does not match up with the financial and physical outlay during the farming period, probably due to adverse effect of the climate variations.

As shown in table 4, reduction in crop productivity has the highest mean score of 4.30; here, an average number of the rice farmers strongly agreed that the reduction in crop productivity was evident.

The other most negatively perceived elements of climate change were its effect on farmers' income and crop health with respect to pest infestation and disease outbreak - these two turned up with mean scores of 4.14 and 4.13 respectively.

\section{Vulnerability Assessment Index Score}

The vulnerability assessment index of 0.3001 (a measure of the exposure, susceptibility and resilience/capacities of rice farmers) indicates that the study area is prone to the adverse effect of climate; this could be adduced to the problem of constant flooding occasioned by proximity to the river Niger. This high value has a negative effect on their livelihood as their livelihood is threatened. The high value might be because they are highly exposed and susceptible to climatic induced hazards coupled with low adaptive capacity. The results of the different indices is shown in tables 5, 6 and 7 .

The vulnerability assessment index of 0.3001 indicates that the zone is prone to the adverse effect of climate The Composite Vulnerability Index $\left(\mathrm{CI}_{v}\right)$ of rice farmers was calculated as follows:

$$
\mathrm{CI}_{\mathrm{v}}=\mathrm{W}_{\mathrm{e}} \times \mathrm{I}_{\mathrm{v}} \mathrm{E}+\mathrm{W}_{\mathrm{s}} \times \mathrm{I}_{\mathrm{v}} \mathrm{S}-\mathrm{W}_{\mathrm{c}} \times \mathrm{I}_{\mathrm{v}} \mathrm{C}
$$

Where

$\mathrm{CI}_{\mathrm{V}}=$ Composite Vulnerability Index of the farmer's

$\mathrm{W}_{\mathrm{e}}=$ exposure weight $=1$;

$\mathrm{W}_{\mathrm{s}}=$ susceptibility weight $=0.5$

$\mathrm{W}_{\mathrm{c}}=$ capacity weight $=0.5$

$\mathrm{I}_{\mathrm{v}} \mathrm{E}=$ vulnerability index of rice farmers due to exposure

$\mathrm{I}_{\mathrm{v}} \mathrm{S}=$ vulnerability index of rice farmers due to susceptibility

$\mathrm{I}_{\mathrm{V}} \mathrm{C}=$ Index of resilience/capacities of rice farmers in the study area.

$$
\begin{gathered}
\mathrm{CI}_{\mathrm{v}}=1.0 \times 0.4497+0.5 \times 0.0689-0.5 \times 0.3681 \\
\mathrm{CI}_{\mathrm{v}}=0.4497+0.0345-0.1841 \\
\mathrm{CI}_{\mathrm{v}}=0.4842-0.1841 \\
\mathrm{CI}_{\mathrm{v}}=0.3001
\end{gathered}
$$


Table 3. Awareness about climate elements

\begin{tabular}{l|cc}
\multicolumn{1}{c|}{ Awareness } & Categories & Percentage \\
\hline Are you aware of climate change? & Yes & 87.1 \\
Have you for once been affected by climate change? & Yes & 75.9 \\
Is there a change in the amount of rainfall? & Yes & 92.5 \\
Is there a change in the timing of the rain? & Yes & 80.3 \\
Is rainfall predictable? & Yes & 40.7 \\
Is there late cessation of rain? & Yes & 66.7 \\
Is there any noticeable change in the timing of the raining season? & Yes & 80.4 \\
Is there any change in the length of the raining season? & Yes & 75.7 \\
Have you experienced flood in your community? & Yes & 66.7 \\
Is there increase in the length of temperature? & Yes & 79.6 \\
Is there decrease in the length of temperature? & Yes & 54.6 \\
Are you affected by the extreme temperature? & \multicolumn{2}{c}{} \\
\hline
\end{tabular}

Source: Field Survey, 2019

Table 4. Perception of Farmers on Climate Change Effect

\begin{tabular}{l|cc}
\hline \multicolumn{1}{c|}{ Perception } & Mean score & Rank \\
\hline Reduction in crop productivity & 4.30 & $1 \mathrm{st}$ \\
Farmers' income seriously affected & 4.14 & $2 \mathrm{nd}$ \\
Crop pest infestation and disease outbreak & 4.13 & $3 \mathrm{rd}$ \\
Increase in price of food & 4.03 & 4 th \\
High temperature & 3.98 & 5 th \\
High occurrence of flood & 3.86 & 6 th \\
Delay in rainfall & 3.83 & 7 th \\
Food shortage/insecurity & 3.49 & 8 th \\
Reduction in amount of rainfall & 3.29 & 9 th \\
Rural urban migration & 3.23 & 10 th \\
Reduction in livestock productivity & 3.22 & 11 th \\
Reduction in crop production & 3.18 & 12 th \\
Reduction in forest resources & 3.04 & 13 th \\
High mortality rate of livestock & 2.95 & 14 th \\
\hline
\end{tabular}

Source: Field Survey, 2019

Table 5. Exposure index according to variation in yield, pest infestation, flood disaster, drought, extreme temperature and bush burning

\begin{tabular}{l|ccc|c}
\hline Exposure indicators & $\begin{array}{c}\text { Variance Value of } \\
\text { indices (X) }\end{array}$ & $\begin{array}{c}\text { Normalized value of } \\
\text { exposure indices }\end{array}$ & $\begin{array}{c}\text { Weight of exposure } \\
(\mathrm{Wy})\end{array}$ & $\begin{array}{c}\text { Index of Exposure } \\
\text { indices }(\mathrm{Wy} \times \mathrm{Ny})\end{array}$ \\
\hline Variation in rainfall & 2.055 & 0.191 & 1 & 0.191 \\
Pest infestation & 3.279 & 0.590 & 1 & 0.590 \\
Flood occurrence & 4.537 & 1.000 & 1 & 1.000 \\
Drought & 2.175 & 0.230 & 1 & 0.230 \\
Extreme temperature & 3.583 & 0.689 & 1 & 0.689 \\
Bush burning & 1.471 & 0.001 & 1 & 0.001 \\
\hline Sum of Indices & & & 2.698 \\
Exposure Indices =sum of indices/no. of indicators
\end{tabular}

Source: Field survey, 2019

Table 6. Susceptibility index according to soil condition, crop yield, access to information, access to credit loan and average income

\begin{tabular}{l|ccc|c}
\hline Susceptibility indices & $\begin{array}{c}\text { Variance Value of } \\
\text { indices (X) }\end{array}$ & $\begin{array}{c}\text { Normalized value of } \\
\text { susceptibility indices }\end{array}$ & $\begin{array}{c}\text { Weight of } \\
\text { susceptibility (Wy) }\end{array}$ & $\begin{array}{c}\text { Index of } \\
\text { Susceptibility } \\
\text { indices (Wy Ny) }\end{array}$ \\
\hline Soil condition & 0.159 & -0.057 & 0.5 & -0.029 \\
Crop yield & 0.231 & 0.015 & 0.5 & 0.008 \\
Access to information & 0.239 & 0.023 & 0.5 & 0.012 \\
Access to credit loan & 0.245 & 0.029 & 0.5 & 0.015 \\
Average income & 0.895 & 0.679 & 0.5 & 0.340 \\
\hline Sum of Indices & & & 0.345 \\
Susceptibility Indices =sum of indices/no. of indicators &
\end{tabular}

Source: Field survey, 2019 
Table 7. Capability index according to income diversification, insurance scheme, use of improved seed, improved practices and agro-forestry

\begin{tabular}{l|ccc|c}
\hline \multicolumn{1}{c}{ Capacity indicators } & $\begin{array}{c}\text { Variance Value of } \\
\text { indices (X) }\end{array}$ & $\begin{array}{c}\text { Normalized value of } \\
\text { capacity indices }\end{array}$ & $\begin{array}{c}\text { Weight of capacity } \\
(\mathrm{Wy})\end{array}$ & $\begin{array}{c}\text { Index of Capacity } \\
\text { indices }(\mathrm{Wy} \times \mathrm{Ny})\end{array}$ \\
\hline Income diversification & 1.468 & 0.823 & 0.5 & 0.412 \\
Taking up insurance & 1.255 & 0.990 & 0.5 & 0.495 \\
Use of improved seeds & 2.524 & 0.001 & 0.5 & 0.001 \\
Improved practices & 1.412 & 0.867 & 0.5 & 0.434 \\
Agro-forestry & 1.242 & 1.000 & 0.5 & 0.500 \\
\hline Sum of Indices & & & 1.841 \\
Capacity Indices = sum of indices/no. of indicators
\end{tabular}

Source: Field survey, 2019

\section{Coping Strategies Adopted}

Figure 1 shows that majority of the farmers despite being vulnerable to climate change claimed not to have adopted any coping strategies. With a mean score of 0.89 , the first on the ranking indicated: "not to do nothing when it comes to coping practices other than trust God and that there will be no flooding". The second on the ranking with mean score of 0.78 stated that "they engaged in (planting trees) forestry in preventing flooding", while some other respondents claimed to have "taking up insurance in the eventuality of flooding"; a few of them "engage in construction of drainage system in order to channel water to appropriate quarters".

The why most of the farmers do adopt any coping strategies but by trusting in God is as a result of lack proper awareness. A multi-media enlightenment campaign of the effects and possible coping strategies of climate change should be adopted by all tiers of government and NGOs to reach the farmers using available extension structure on ground. Also, farming communities can run local disaster risk committees to encourage local adaptation measures as survival tactics for the purpose of ensuring food security.

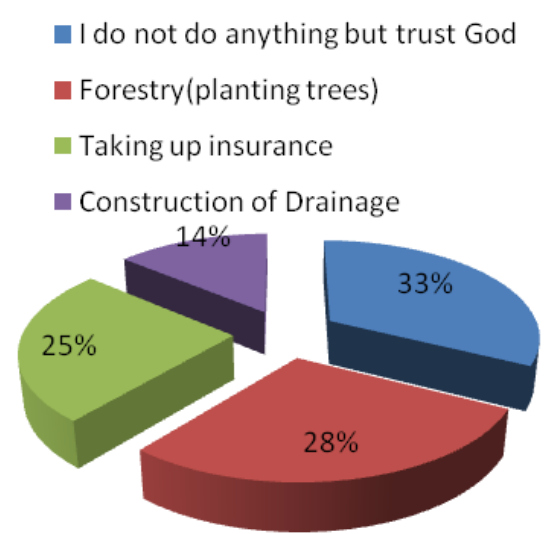

Figure 1. Coping Strategies Adopted by Rice Farmers.

\section{Conclusion and Recommendations}

The study found that rice farmers in Kwara State, Nigeria farmers are vulnerable to the adverse effects of climate. Majority of them affirmed that they were affected by this climate change in the course of rice production but do not possess adequate knowledge of management strategies. In order to mitigate the effect of climate change effect and consequent reduction in rice yield, some of the rice faming households engaged in tree planting, while few of them took up insurance in the eventuality of flooding, and construction of flood-control drainage system. Therefore, in the face of changing weather patterns, farmers should be trained on sustainable cultural and management practices that could help mitigate the loss of rice. The rice farmers should be enjoined to plant more drought tolerant and early maturing varieties of rice. Capacity building of the farmers should be done so as to strengthen their preparation against the effects of climate change and improve their production, and this is with a view of exposing the farmers to effective mitigation strategies.

\section{References}

Adger WN, Dessai S, Goulden M, Hulme M, Lorenzoni I, Nelson DR, Naess LO, Wolf J, Wreford A. 2009. Are there social limits to adaptation to climate change? Climatic Change 93: $335-354$.

Coumou D, Rahmstorf S. 2012. A decade of weather extremes. Nature Climate Change, 2:491-496.

Hatfield JL, Boote KJ, Kimball BA, Ziska LH, Izaurralde RC, Ort D, Thomson AM, Wolfe D. 2011. Climate impacts on agriculture: Implications for crop production. Agronomy Journal, 103, 351-370.

Jackson L, van Noordwijk M, Bengstsson J, Foster W, Lipper L, Pulleman M, Vodouhe R. 2010. Biodiversity and agricultural sustainability: From assessment to adaptive management. Current Opinion in Environmental Sustainability, 2, 80-87.

Kwara Agricultural Development Project (KWADP) (2018). Kwara State Agricultural Development Project, under the Ministry of Agriculture and Rural development, Ilorin, Kwara available from State.www.kwarastate.gov.ng (accessed 15 July, 2019).

Nigg JM, Mileti D. 2002. Natural hazards and disasters. In Dunlap R. E., Michelson W. (Eds.), Handbook of environmental sociology (pp. 272-294). Westport, CT: Greenwood Press. [Google Scholar]

Nwajiuba C. 2013. Nigeria's Agriculture and Food Security Challenges. 1st ed. [ebook] Nigeria: Boell p.45. Available at https://ng.boell.org/sites/default/files/uploads/2013/10/agricult ure__green_deal_nigeria_study.pdf [Accessed 5 May 2017].

Punch 2018, http://punch.com/flood-sacks-five-kwaracommunities [Accessed 5 May 2018].

Slovic P. 2009. The perception of risk. Earthscan, London, England.

Smithers J, Smit B. 1997. Human adaptation to climatic variability and change. Global Environmental Change 7 (3):129-146.

The Organisation for Economic Co-operation and Development (OECD). Handbook on Constructing Composite Indicators. Methodology and User Guide; Joint Research CentreEuropean Commission: Paris, France, 2008. 
Uba G 2013. Nigeria Investing in Rice Processing Project. ThisDay Newspaper 15th Jan 2013.

UNDP 2006. Human Development Report, United Nations Development Programme. Available at: http://hdr.undp.org/ hdr2006/statistics (accessed 15 July, 2019). UNFCCC 2007. "Climate Change impact vulnerability and adaptation in Developing countries", Bonn.
USDA 2018. Production, supply and distribution online. Retrieved from https://apps.fas.usda.gov/psdonline/app/ index.html\#/app/home (accessed 15 July, 2019).

Zoellick RB. 2009. A Climate Smart Future, the Nation Newspapers. Vintage Press Limited, Lagos, Nigeria 18 